\title{
ORGANIC GEOCHEMICAL CHARACTERISTIC OF CRUDE OILS FROM ORANGE GRABEN, SOUTH SUMATRA BASIN
}

\author{
M. Syaifudin ${ }^{1, *}$ \\ ${ }^{1}$ Geology-FTM, Universitas Pembangunan Nasional “Veteran” Yogyakarta, Indonesia
}

Corresponding author: syaifudin_muhammad@yahoo.com

Tel.: 0812-2793-352

Received: Oct 1, 2016. Revised : Nov 15, 2016, Accepted: Nov 20, 2016, Published: 1 Dec 2016

DOI : 10.24273/jgeet.2016.11.3

Abstract

Lemat Formation in the Orange Graben in the South Sumatra basin has been considered as syn-rift sediments consist of fluvio-lacustrine sediments, create source rock with fluvio-lacustrine characterize. Based on existing publications, showing that the oils from Orange Graben have fluvio-deltaic characterization and generated by source rock from Talangakar Formation with fluvio-deltaic depositional environment.

This paper emphasizes geochemistry methods. Source rock analysis, consist of 26 samples for carbon isotope and 14 samples for biomarker, while oil analysis, consist of 15 samples for carbon isotope and 19 samples for biomarker. Characterization has been based on qualitative and quantitative data. Qualitative data comprise evaluation based on chromatograms and mass-fragmentograms, whereas quantitative data consists of a series of cross-plots, eg. cross plot of carbon isotope $\delta^{13} \mathrm{C}$ saturates - aromatics, distribution of $\mathrm{C}_{27}-\mathrm{C}_{28}-\mathrm{C}_{29}$ sterane, $\mathrm{Pr} / \mathrm{nC}_{17}-\mathrm{Ph} / \mathrm{nC}{ }_{18}, \mathrm{Pr} / \mathrm{Ph}-\mathrm{Pr} / \mathrm{nC} \mathrm{C}_{17}$, carbon isotope $\delta^{13} \mathrm{C}$ saturates- $\mathrm{Pr} / \mathrm{Ph}, \mathrm{Pr} / \mathrm{Ph}$-total hopane/total sterane, and ratio of $\mathrm{C}_{26} / \mathrm{C}_{25}$ (tricyclic).

Based on geochemical result of analysis, source rocks of Lemat Formation in the Orange Graben interpret as source rock with fluvio-deltaic characterize, have terrestrial influence while Talangakar Formation in the Orange Graben interpreted as source rock with deltaic characterization, having marine and terrestrial influence. Both of them , consist of humic kerogen. Whereas, oil samples in the Orange Graben interpreted as oilwhich is generated by source rock with fluvio-deltaic characterization, having terrestrial influence, in anoxic-suboxic-oxic conditions, consisting of humic kerogen. Correlation result between source rocks and oils in the Orange Graben, indicating that fluvio-deltaic oil type in the Orange Graben are correlate with not only the source rocks of Talangakar Formations but also with source rock of Lemat Formation.

Key words: Geochemistry, Crude Oil, Biomarker, Carbon Isotope, Fluvio-Lacustrine-Deltaic.

\section{Introduction}

South Sumatra Basin is a potential and mature basin for hydrocarbon source. There are a number of sub-basins which is potential as the hydrocarbon source in this basin. Orange Graben is one of sub-basin on the South Palembang SubBasin, formed in Upper Cretaceous to Lower Tertiary, in extensional phase, this is the beginning of sedimentation in this area.

Lemat Formation in Orange Graben has been considered as syn-rift sediments consist of terrestrial sediment (fluvio-lacustrine), creating source rock with fluvio-lacustrine characterization. While based on existing publications, showing that oil from Orange Graben have fluvio-deltaic characterize and generated by source rock from Talangakar Formation with fluvio-deltaic characterization.

This is interesting to study further, especially about possibility of source rock with fluviolacustrine characterization in research area. This study emphasized to source rocks of Lemat and Talangakar Formation in Orange Graben, South Palembang Sub-Basin, South of Sumatra Basin.

\section{Location of Study Area}

The study area located in Orange Graben, South of Sumatra (Figure 1).

\section{Research Methods}

The basic source rock analyses comprise screening, kerogen typing, and maturation. Further analysis, such as correlation between source rock and crude oil as well as crude oil to crude oil, has been done by using more sophisticated techniques, i.e. carbon isotope and biomarkers. Source rock analysis, consist of 26 samples for carbon isotope and 14 samples for biomarker, while oil analysis, consist of 15 samples for carbon isotope and 19 samples for biomarker. Characterization has been based on qualitative and quantitative data. Qualitative data comprise evaluation based on chromatograms and mass-fragmentograms, whereas quantitative data consists of a series of cross-plots, eg. cross plot of carbon isotope $\delta^{13} \mathrm{C}$ saturates-aromatics, distribution of $\mathrm{C}_{27}-\mathrm{C}_{28}-\mathrm{C}_{29}$ sterane, $\mathrm{Pr} / \mathrm{nC}_{17}-\mathrm{Ph} / \mathrm{nC}_{18}$, $\mathrm{Pr} / \mathrm{Ph}-\mathrm{Pr} / \mathrm{nC}_{17}$, carbon isotope $\delta^{13} \mathrm{C}$ saturates-Pr/Ph, $\mathrm{Pr} / \mathrm{Ph}$ - total hopane/total sterane, and ratio of $\mathrm{C}_{26} / \mathrm{C}_{25}$ (tricyclic). 


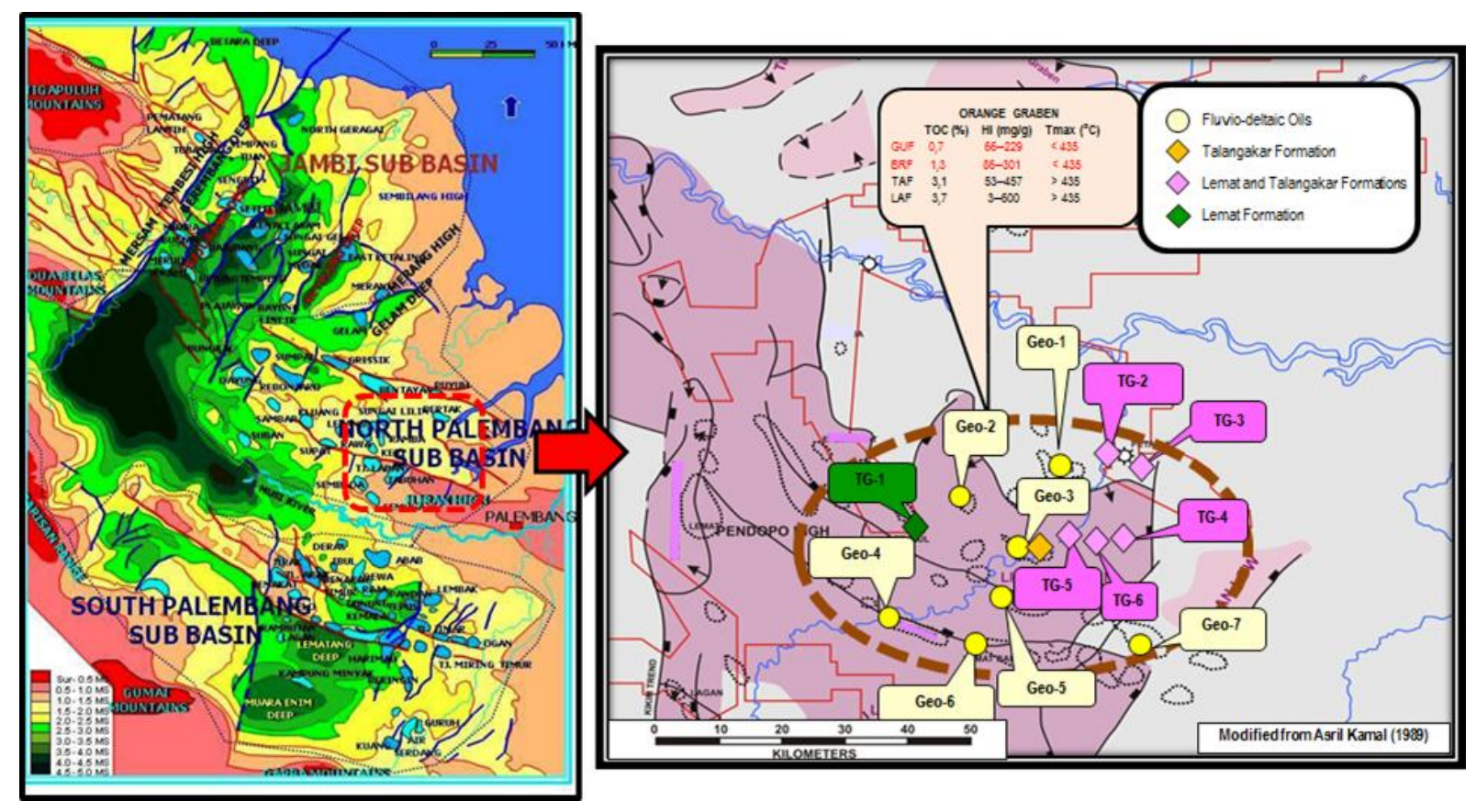

Fig 1. Location map of the study area and data of source rocks in Orange Graben.

The results of this study expected could explain the character of source rocks and oil in the Orange Graben, also to find out the possibility of lacustrine source rock existence and determine the correlation between source rocks and oils in this area, so can be known whether Lemat Formation source rocks also have contributed to produce oil in this area or not. In addition, to provide a new opportunity in the exploration of hydrocarbons in the Orange Graben which considered as a mature and potential basin for hydrocarbon.

\section{Regional Geology}

The evolution of the South Sumatra Basin started in the Mesozoic Era (Pulunggono et al., 1992) (25) as a back-arc basin (Figure 2). Back-arc basins in Indonesia are generally hydrocarbon prolific basins. The mechanism involved in the basin formation is general rifting, which formed a graben or half graben. This basin was formed in two phases, i.e. the rifting phase occured during the Paleogene and the sagging during the Neogene. The rifting phase is characterized by the thinning of crust forming Graben or half Graben, whereas the sagging phase is characterized by stable tectonics, and even a change in tectonic compression, which finished with volcanic activities that are shown by the occurrence of tuff that appeared in the Air Benakat Formation. The rifting phase was filled by the Lahat Group that is comprised of the Benakat and Lemat Formations, whereas the sagging phase was filled with sediments from the Talangakar Formation up to the youngest formation, i.e. Kasai Formation (Figure 3).

\section{Characterization of Source Rocks and oils in Orange Graben}

\subsection{Quantitative Method}

Pristane/phytane (Pr/Ph) ratios have been used to assess the redox potential of the depositional environment and source of organic matter (Didyk et al., 1978 (10); Tissot and Welte, 1984 (31); Zhang and Huang, 2005 (38); Peters et al., 2005 (22); Duan et al., 2008 (11); Hao et al. 2011 (18); Cheng et al., 2013 (7) and Tao et al., 2015 (9) or reflect the relationship between contributing organisms and the chemistry of the environment (Mello and Maxwell, 1990) (20).

Figure 4 shows a cross plot $\mathrm{Pr} / \mathrm{nC}_{17}-\mathrm{Ph} / \mathrm{nC}_{18}$ as proposed by Connan and Cassou (1980) (8) and $\mathrm{Pr} / \mathrm{Ph}-\mathrm{Pr} / \mathrm{nC}_{17}$, source rocks of Lemat and Talangakar Formations, and oils in Orange Graben. This image shows both source rocks of Lemat and Talangakar Formation and oils, consists of humic kerogen in suboxic-anoxic until oxic conditions, but mostly in oxic conditions.

Waples, 1985 (35) stated that on the average, the stable carbon isotope values of the saturated and aromatic hydrocarbons of oils are about $2 \%$ more negative (lighter) than kerogens. A plot of the stable carbon isotope values of the saturated and aromatic hydrocarbons in the source rocks of Lemat and Talangakar Formations and oils in Orange Graben as proposed by Sofer (1984) (27) is shown in Figure 5. This figure shows source rocks of Lemat and Talangakar Formations and oils consists of terrestrial and mixed material, in anoxic-suboxic to oxic conditions, but mostly in oxic conditions.

Figure 6 shows a cross plot of $\mathrm{Pr} / \mathrm{Ph}$ hopane/sterane and sterane distribution $\mathrm{C}_{27}, \mathrm{C}_{28}$, 


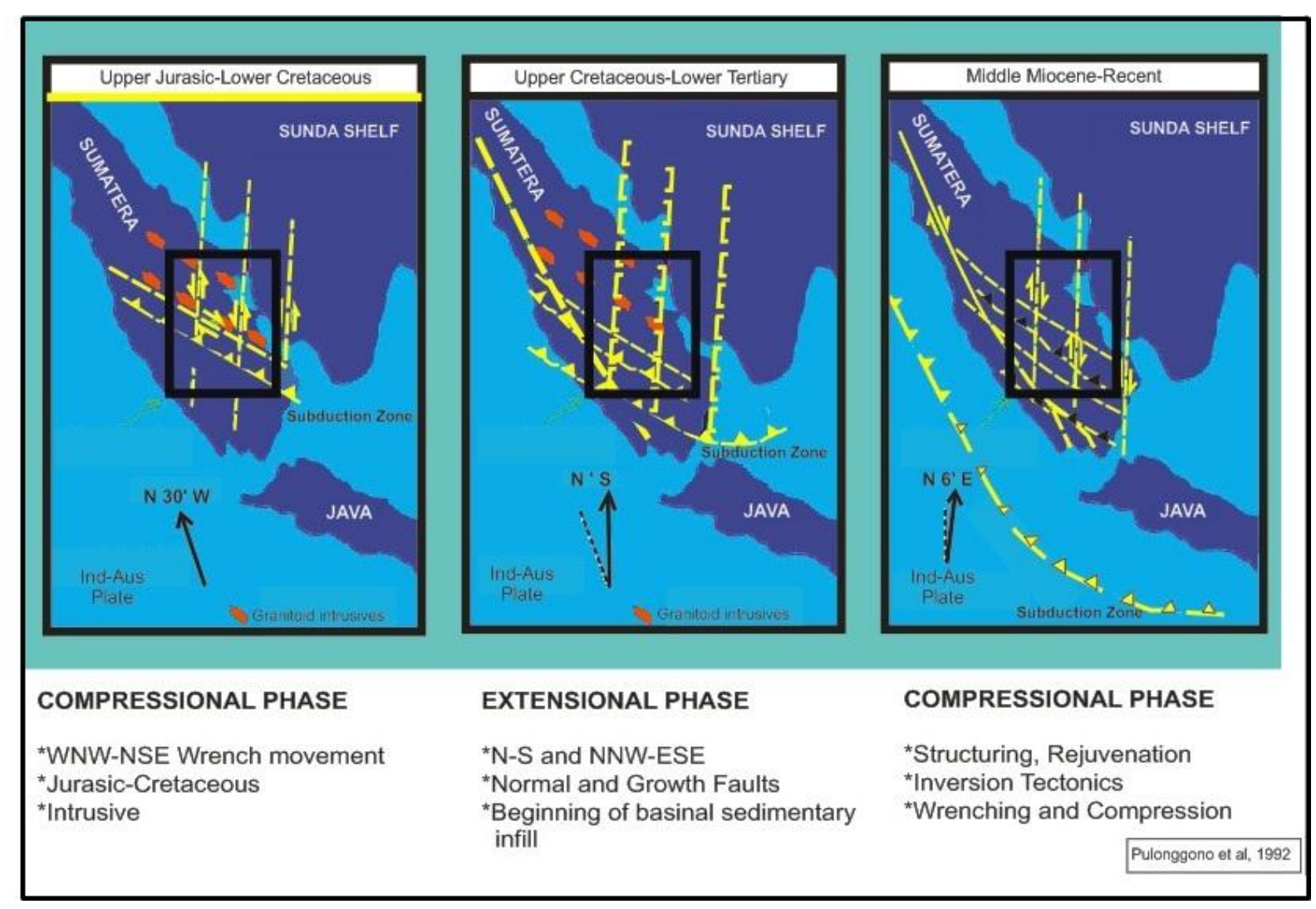

Fig 2. Tectonic evolution of the South Sumatra Basin from Upper Jurassic-now (Pulunggono et al., 1992).

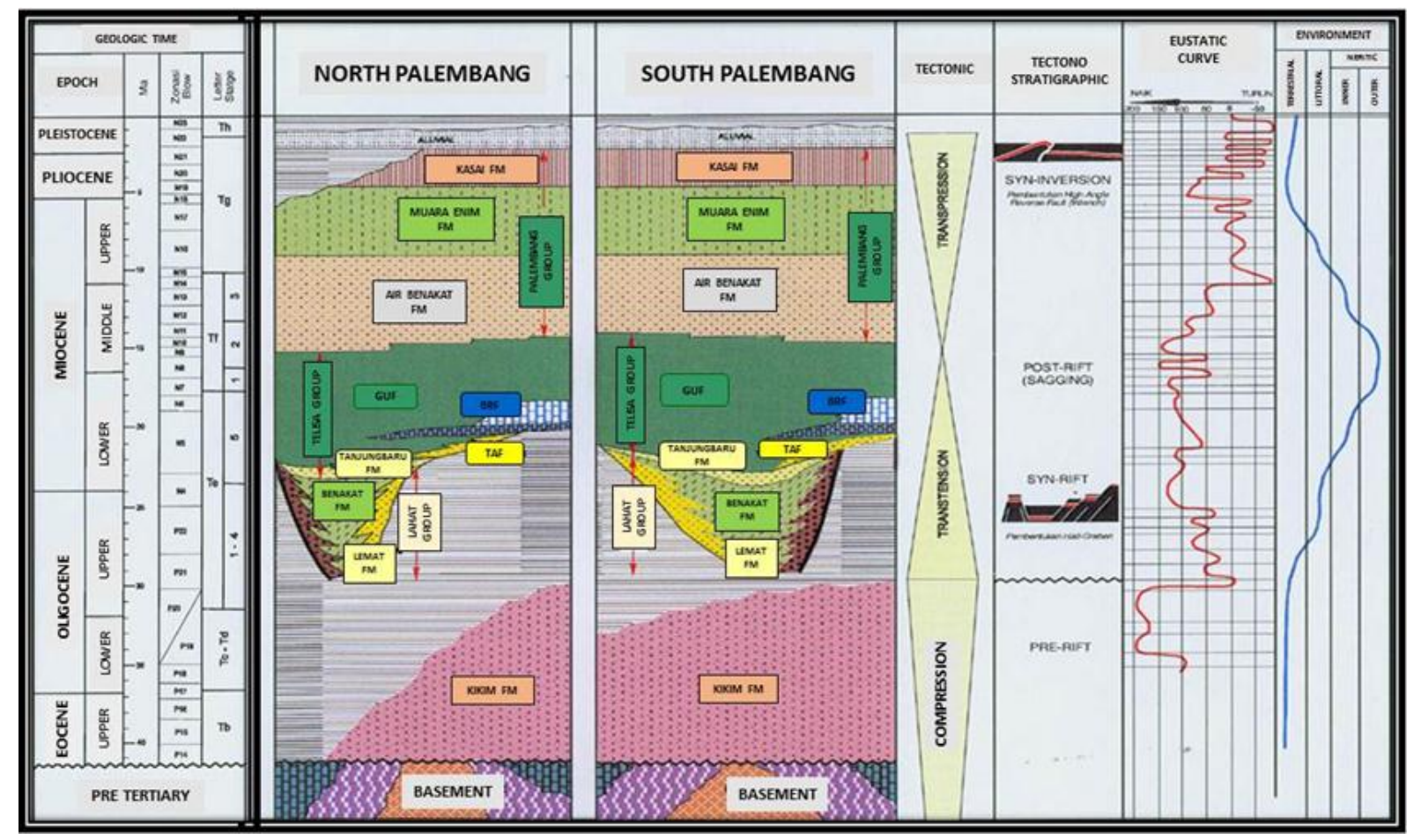

Fig 3. Regional stratigraphy of the South Sumatra Basin (modified from Ryacudu, 2008). 


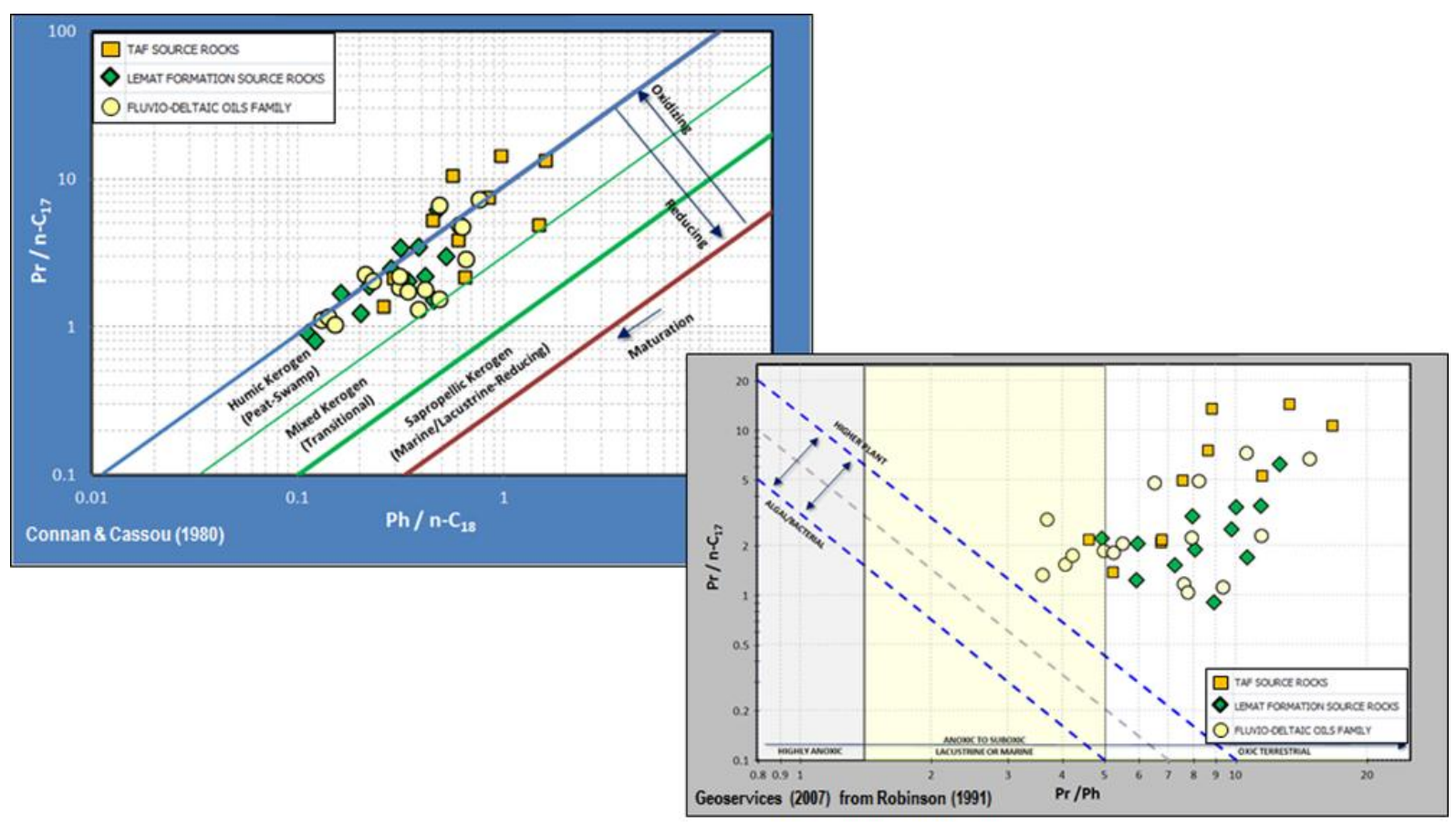

Fig 4. Cross plot of $\mathrm{Pr} / \mathrm{nC}_{17}-\mathrm{Ph} / \mathrm{nC}_{18}$ and $\mathrm{Pr} / \mathrm{Ph}-\mathrm{Pr} / \mathrm{nC}_{17}$, source rocks of Lemat and Talangakar Formation, and oils in Orange Graben.

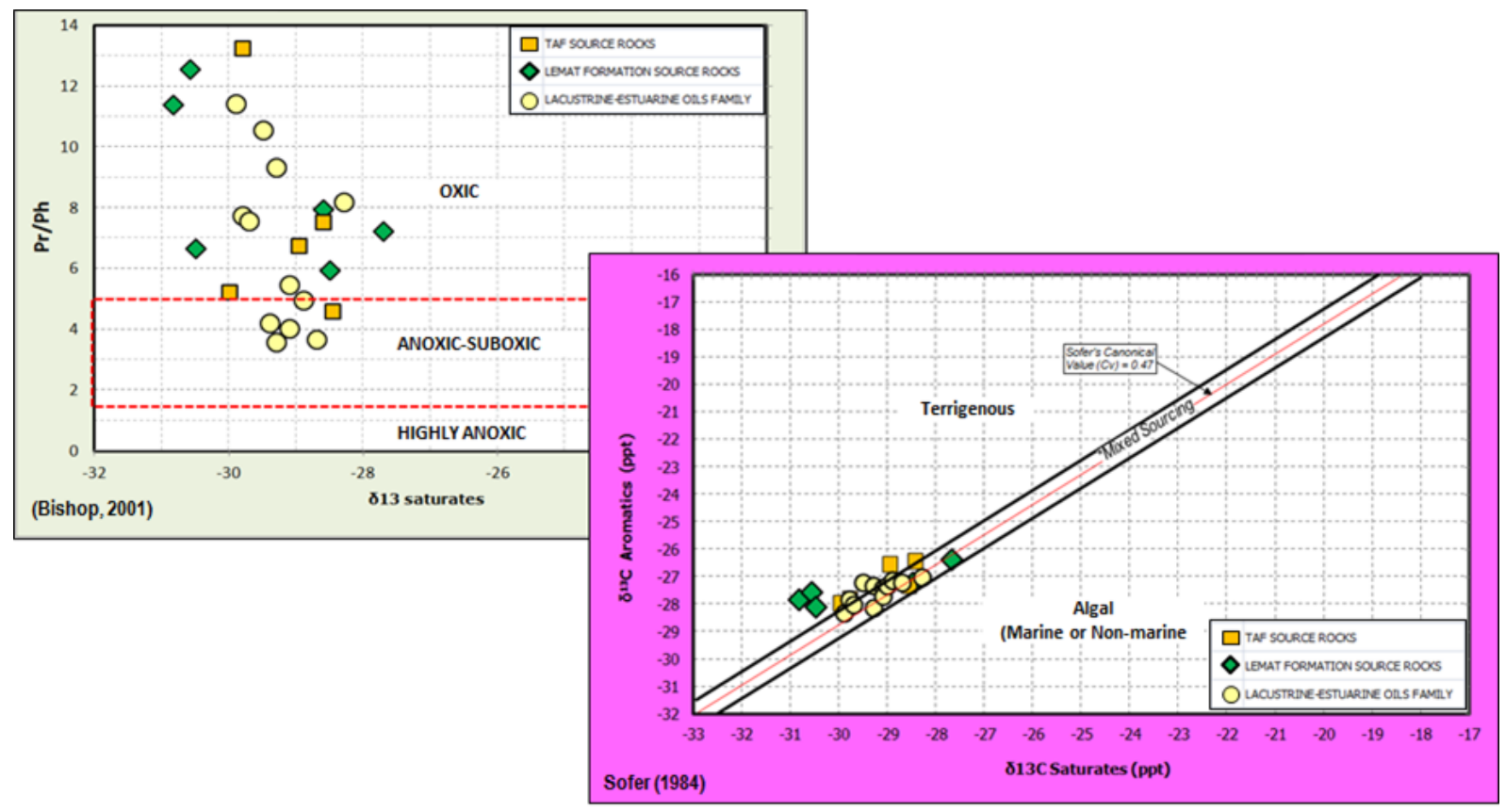

Fig 5. Cross plot of carbon isotope $\partial^{13} \mathrm{C}$ saturates - $\partial^{13} \mathrm{C}$ aromatics and carbon isotope $\partial^{13} \mathrm{C}$ saturates - $\mathrm{Pr} / \mathrm{Ph}$, source rocks of Lemat and Talangakar Formation, and oils in Orange Graben. 
and $\mathrm{C}_{29}$, source rocks of Lemat and Talangakar Formations and oils in Orange Graben. From this picture it appears that the source rocks of Lemat and Talangakar Formations and oils affected by terrestrial material in anoxic-suboxic until oxic conditions, but mostly in high oxic conditions.

It is usually believed that $\mathrm{C}_{27}$ steranes derive mainly from phytoplankton and metazoa, whereas $\mathrm{C}_{29}$ steranes mainly originate from terrigenous higher plants (Huang and Meinschein, 1979 (19); Volkman, 1986 (33)). From the cross plot of sterane distribution $\mathrm{C}_{27}, \mathrm{C}_{28}$, and $\mathrm{C}_{29}$, show Lemat Formation derived from estuarine to terrestrial environments, whereas Talangakar Formation and oils derived from marine, estuarine, and terrestrial environments.

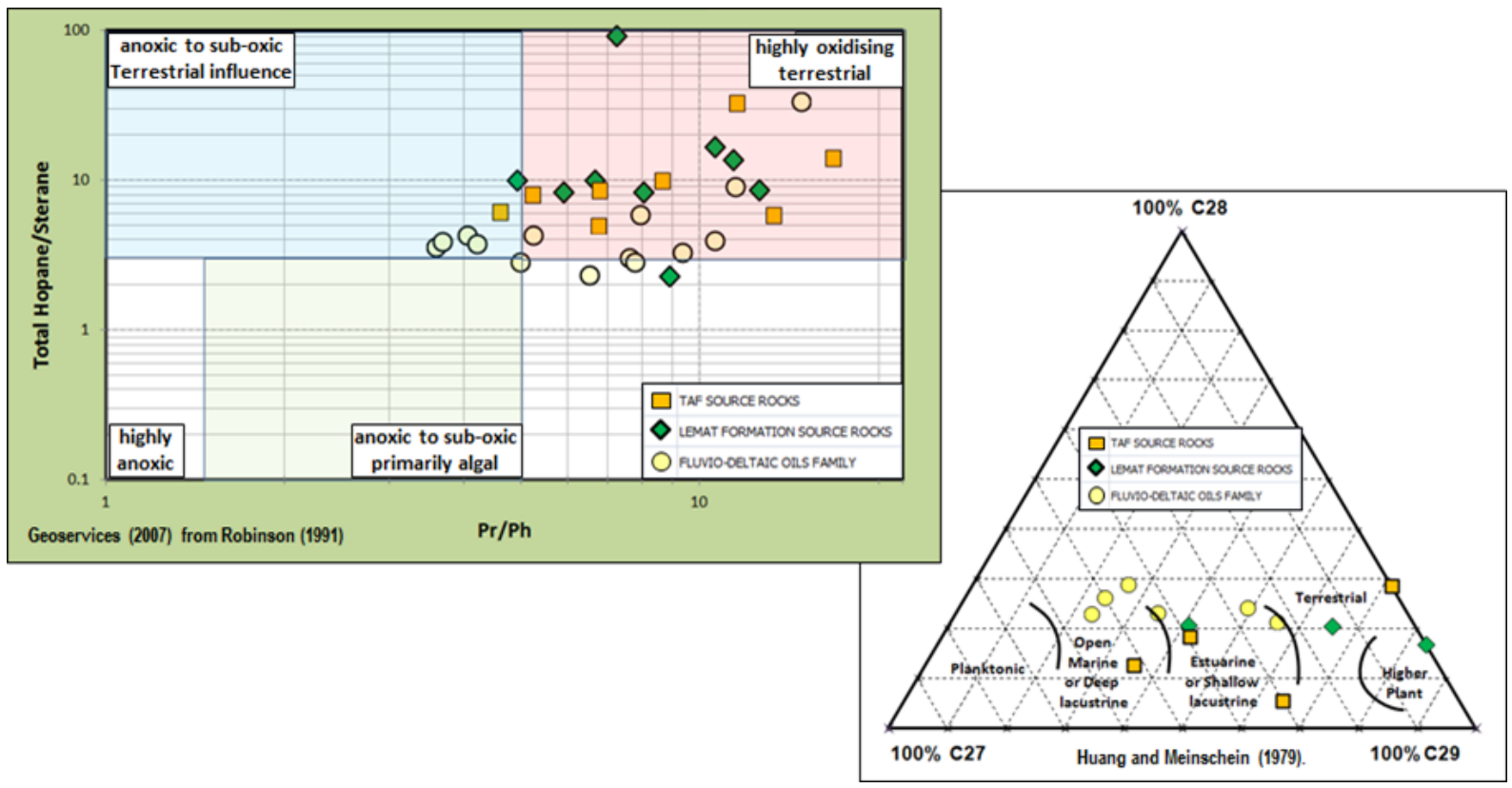

Fig 6. Cross plot of Pr/Ph-hopane/sterane and sterane distribution $\mathrm{C}_{27}, \mathrm{C}_{28}$, and $\mathrm{C}_{29}$, source rocks of Lemat and Talangakar Formation, and oils in Orange Graben.

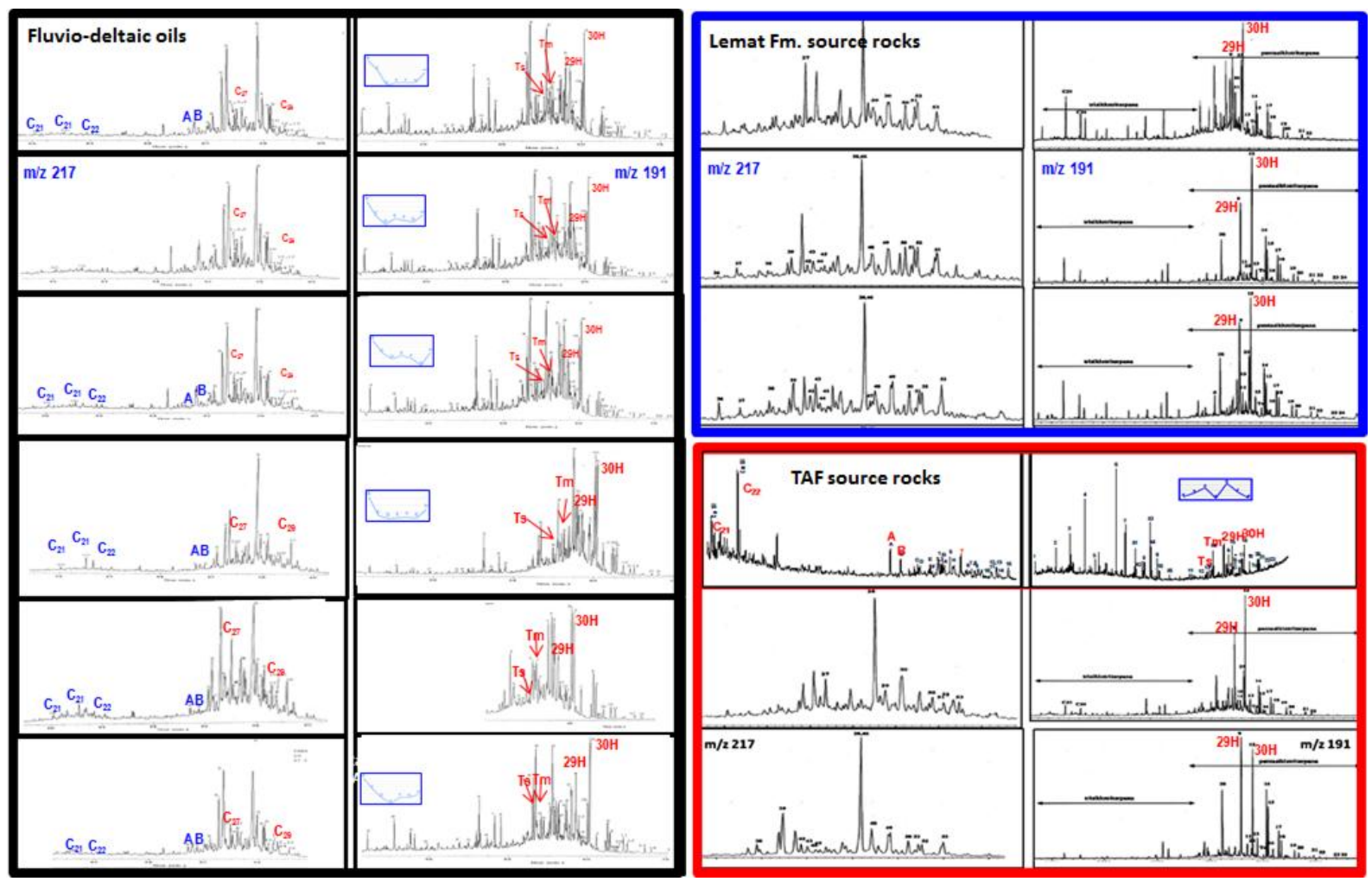

Fig 7. Comparison of biomarker characterization qualitatively between source rocks of Lemat and Talangakar Formation, and oils in Orange Graben 


\subsection{Qualitative Method}

Figure 7 is a comparison of biomarker characterization qualitatively between source rocks of Lemat and Talangakar Formation and oils in Orange Graben. From this picture it appears that source rocks of Lemat and Talangakar Formations and oils, according to ten Haven and Schiefelbein (1995) (30); Peters et al. (2005) (22); Syaifudin et al. (2015) (28) and Tao et al. (2015) (29), is not lacustrine sediments because has $\mathrm{C}_{26} / \mathrm{C}_{25}$ (tricyclic) smaller than 1.

Based on tricyclic data, according to Price et al. (1987) (24), Lemat Formation and oils show terrestrial pattern, whereas Talangakar Formations show marine and terrestrial pattern. Terrestrial is characterized by high $\mathrm{C}_{19}$ and $\mathrm{C}_{20}$ tricyclic (Philp and Gilbert, 1986 (23); Peters and Moldowan, 1993 (21), Hanson et al., 2000 (16); Grice et al., 2001 (14); George et al., 2004 (12); Volk et al., 2005 (32); Zhang and Huang 2005 (38); Peters et al., 2005 (22); Hao et al., 2009 (17); Hao et al., 2011 (18); Asif et al., 2011 (4); Adedosu et al., 2012 (1); Tao et al., 2015 (29); Wang et al., 2015 (34)). Lemat, Talangakar Formation and oils show $\mathrm{C}_{19}$ and $\mathrm{C}_{20}$ tricyclic are more abundant. $\mathrm{C}_{23}$ tricyclic is often the dominant in crude oils of a marine source (Aquino Neto et al., 1983 (2); Zumberge, 1987 (40); Burwood et al., 1992 (6); Hanson et al., 2000 (16); Zhang and Huang, 2005 (38); Hakimi et al., 2011 (15); Tao et al., 2015 (29)). Talangakar Formation besides show $\mathrm{C}_{19}$ and $\mathrm{C}_{20}$ tricyclic dominan, also $\mathrm{C}_{23}$ tricyclic dominan. These data indicate Lemat Formation interpreted as fluvio-deltaic sediment, whereas Talangakar Formation having more marine characterization than Lemat Formation.

Based on data of $29 \mathrm{H}$ and $30 \mathrm{H}$ (hopane) distribution, the pattern of $29 \mathrm{H}<30 \mathrm{H}$ indicate marine clastic sediments, while $29 \mathrm{H}>30 \mathrm{H}$ is evaporates-carbonate sediment (Zumberge (1984) (39); Connan et al. (1986) (9); Price et al. (1987) (24); Waples and Machihara (1991) (36); Peters et al. (2005) (22); Hakimi et al. (2011) (15); Xiangchun et al. (2013) (37); Syaifudin et al. (2015) (28), and Wang et al. (2015) (34). The source rocks of Lemat Formation and oils shows $29 \mathrm{H}<30 \mathrm{H}$, while Talangakar Formation not only show $29 \mathrm{H}<30 \mathrm{H}$ but also show $29 \mathrm{H}>30 \mathrm{H}$.

From data of homohopana distribution which decreased regularly from $C_{31}$ to $C_{35}$, interpreted as depositional environment which associated with clastic sediments (Waples and Machihara, 1991 (36)) or more oxidizing conditions (Peters and Moldowan, 1993 (21); Hakimi et al. (2011) (15). The source rock of Lemat, Talangakar Formations, and oils in Orange Graben interpreted as depositional environment which associated with clastic sediments.

Based on these data, oil in the Orange Graben interpreted originated from fluvio-deltaic source rocks and has a correlation with Lemat and Talangakar Formations in Orange Graben.

\section{Conclusion}

Source rocks of Lemat and Talangakar Formations and oils in Orange Graben consists of humic kerogen and terrestrial and mixed material. Source rocks of Lemat and Talangakar Formations and oils in Orange Graben, is not derived from a lacustrine sediments, affected by terrestrial material in anoxic -suboxic until oxic conditions, but mostly on high oxic conditions. Besides, its also looks like Lemat Formations derived from estuarine to terrestrial environments, whereas Talangakar Formation and oils in Orange Graben derived from marine, estuarine, and terrestrial environments. Lemat Formation and oils in Orange Graben show terestrial pattern, whereas Talangakar Formations show marine and terrestrial pattern. These data indicate Lemat Formation interpreted as fluvio-deltaic sediment, whereas Talangakar Formation having more marine characteriztion than Lemat Formation. Oils in the Orange Graben interpreted originated from fluvio-delta source rocks, has a correlation with Lemat Formation and Talangakar Formation in Orange Graben.

\section{Acknowledgements}

We would like to thank the management of Directorate General of Oil and Gas and Medco EP for their permission to publish this paper.

\section{References}

[1] T.A. Adedosu, O.O.Sonibare, J.Tuo, O.Ekundayo, 2012. Biomarkers, carbon isotopic composition and source rock potentials of Awgu coals, middle Benue trough, Nigeria, Journal of African Earth Sciences, 66-67, Elsevier, p 13-21.

[2] F.R. Aquino Neto, J.M.Trendel, A.Restle, J.Connan, P.A.Albrecht, 1983. Occurrence and formation of tricyclic and tetracyclic terpanes in sediments and petroleums. In: Bjorøy, M., et al. (Eds.), Journal Advances in Organic Geochemistry, John Wiley and Sons, p 659-667.

[3] E.Artono, B.Tamtomo, 2000. Pre Tertiary reservoir as a hydrocarbon prospecting opportunity in the South Sumatra basin, Western Indonesia in the third millennium, AAPG International Conference and Exhibition, Bali, Indonesia.

[4] M.Asif, T.Fazeelat, K.Grice, (2011). Petroleum geochemistry of the Potwar Basin, Pakistan: 1. Oiloil correlation using biomarkers, $\delta 13 \mathrm{C}$ and $\delta \mathrm{D}$, Journal Organic Geochemistry 42, Elsevier, $p$ 1226-1240.

[5] M.G.Bishop, 2001. South Sumatra Basin Province, Indonesia: The Lahat/Talang Akar-Cenozoic Total Petroleum System, U.S. Geological Survey, OpenFile Report 99-50-s.

[6] R.Burwood, P.Leplat, B.Mycke, J.Paulet, 1992. Rifted margin source rock deposition: a carbon isotope and biomarker study of a west African Lower Cretaceous "lacustrine" section, Journal Organic Geochemistry 19, Pergamon Press Ltd, p 41-52.

[7] P.Cheng, X.M.Xiao, H.Tian, B.J.Huang, R.W.T.Wilkins, Y.ZZhang, 2013. Source controls on geochemical characteristics of crude oils from the Qionghai Uplift in the western Pearl River Mouth 
Basin, offshore South China Sea, Journal Marine and Petroleum Geology 40, Elsevier, p 85-98.

[8] J.Connan, A.M.Cassou, 1980. Properties of gases and petroleum liquids derived from terrestrial kerogen at various maturation levels, Journal Geochimica et Cosmochimica Acta 44, Pergamon Press, p 1-23.

[9] J.Connan, J.Bouroullec, D.Dessort, P.Albrecht, 1986. The microbial input in carbonate-anhydrite facies of a sabkha palaeoenvironment from Guatemala: a molecular approach. Journal Organic Geochemistry 10, Pergamon Press, p 29-50.

[10] B.M.Didyk, B.R.T.Simoneit, S.C.Brassell, G.Eglinton, 1978. Organic geochemical indicators of palaeoenvironmental conditions of sedimentation, Journal Nature 272, p 216-222.

[11] Y.Duan, C.Y.Wang, C.Y.Zheng, B.X.Wu, G.D.Zheng, 2008. Geochemical study of crude oils from Xifeng oilfield of Ordos Basin, China, Journal Asian Earth Sci. 31, Elsevier, p 341-356.

[12] S.C.George, M.Lisk, P.J.Eadington, 2004. Fluid inclusion evidence for an early, marine-sourced oil charge prior to gas-condensate migration, Bayu-1, Timor Sea, Australia, Journal Marine and Petroleum Geology 21, Elsevier, p 1107-1128.

[13] Geoservices, 2007. Geochemistry of oil and gas samples from Gegas 1, South Sumatra PSC, Indonesia, PT Geoservices (Ltd), Report No 2007/0606/LAB, prepared for BPMIGAS Medco E and $P$, not published.

[14] K.Grice, M.Audino, R.Alexander, C.J.Boreham, R.I.Kagi, 2001. Distributions and stable carbon isotopic compositions of biomarkers in torbanites from different palaeogeographical locations. Journal Organic Geochemistry 32, Elsevier, p 195211.

[15] M.H.Hakimi, W.H.Abdullah, M.R.Shalaby, 2011. Organic geochemical characteristics of crude oils from the Masila Basin, eastern Yemen, Journal Organic Geochemistry 42, Elsevier, p 465-476.

[16] A.D.Hanson, C.Zhang, J.M.Moldowan, D.G.Liang, B.M.Zhang, 2000. Molecular organic geochemistry of the Tarim Basin, north-west China. American Association of Petroleum Geologists Bulletin 84, 1109-1128.

[17] F.Hao, X.H.Zhou, Y.M.Zhu, Y.Y.Yang, 2009. Mechanisms for oil depletion and enrichment on the Shijiutuo uplift, Bohai Bay basin, China, American Association of Petroleum Geologists Bulletin 93, 1015-1037.

[18] F.Hao, X.Zhou, Y.Zhu, Y.Yang, 2011. Lacustrine source rock deposition in response to co-evolution of environments and organisms controlled by tectonic subsidence and climate, Bohai Bay Basin, China, Journal Organic Geochemistry 42, Elsevier, p 323-339.

[19] W.Y.Huang, W.G.Meinschein, 1979. Sterols as ecological indicators, Journal Geochimica et Cosmochimica Acta 43, Pergamon Press, p 739745.

[20] M.R.Mello, J.R.Maxwell, 1990. Organic geochemical and biological marker characterization of source rocks and oils from lacustrine environments in the Brazilian continental margin. In: Katz, B.J. (Ed.), Lacustrine Basin Exploration, vol. 50. American Association of Petroleum Geologists Memoir, 7797.

[21] K.E.Peters, J.M.Moldowan, 1993. The Biomarker guide, Interpreting molecular fossils in petroleum and ancient sediments, Prentice Hall, Englewood Cliffs, New Jersey, 1-363.
[22] K.E.Peters, C.C.Walters, J.M.Moldowan, 2005. The Biomarker guide, Cambridge University press, 11155.

[23] R.P.Philp, T.D.Gilbert, 1986. Biomarker distributions in oils predominantly derived from terrigenous source material. In: Leythaeuser, D., Rullkötter, J. (Eds.), Advances in Organic Geochemistry 1985. Journal Organic Geochemistry 10. Pergamon, Oxford, 73-84.

[24] P.L.Price, T.O.Sullivan, R.Alexander, 1987. The Nature and occurrence of oil in Seram, Indonesia Proceedings Indonesia Petroleum Association, sixteenth Annual Convention, Jakarta, Indonesia.

[25] A.Pulunggono, H.S.Agus, C.G.Kosuma, 1992. PreTertiary and Tertiary fault systems as a framework of the South Sumatra basin; A Study of SAR maps, Proceedings Indonesian Petroleum Association, twenty first Annual Convention and Exhibition, Jakarta, Indonesia, 339-360.

[26] R.Ryacudu, 2008. Tinjauan stratigrafi Paleogen Cekungan Sumatra Selatan, Sumatra Stratigraphy Workshop, Ikatan Ahli Geologi Indonesia, 99-114.

[27] Z.Sofer, 1984. Stable carbon isotope compositions of crude oils: application to source depositional environments and petroleum alteration, American Association of Petroleum Geologists Bulletin 68, 31-49.

[28] M.Syaifudin, E.A.Subroto, D.Noeradi, A.H.P.Kesumajana, 2015. Characterization and correlation study of source rocks and oils in Kuang area, South Sumatra basin: the potential of Lemat formation as hydrocarbon source rocks, Proceedings Indonesian Petroleum Association, Thirty-Ninth Annual Convention and Exhibition, Jakarta, Indonesia.

[29] S.Tao, C.Wang, J.Du, L.Liu, Z.Chen, 2015. Geochemical application of tricyclic and tetracyclic terpanes biomarkers in crude oils of NW China, Journal Marine and Petroleum Geology 67, Elsevier, p 460-467.

[30] ten Haven and Schiefelbein, 1995. The petroleum systems of Indonesia, Proceedings Indonesian Petroleum Association, twenty fourth Annual Convention, Jakarta, Indonesia, 443-459.

[31] B.P.Tissot, D.H.Welte, 1984. Petroleum formation and occurence, second revised and enlarge edition, Springer-Verlag, Berlin-Heidelberg-New YorkTokyo, 1-699.

[32] H.Volk, S.George, H.Middleton, S.Schofield, 2005. Geochemical comparison of fluid inclusion and present-day oil accumulations in the Papuan Foreland-evidence for previously unrecognised petroleum source rocks. Journal Organic Geochemistry 36, Elsevier, p 29-51.

[33] J.K.Volkman, 1986. A review of sterol markers for marine and terrigenous organic matter, Journal Organic Geochemistry 9, Elsevier, p 83-99.

[34] G.Wang, X.Chang, T.G.Wang, B.R.T.Simoneit, 2015 Pregnanes as molecular indicators for depositional environments of sediments and petroleum source rocks, Journal Organic Geochemistry 78, Elsevier, p 110-120.

[35] D.W.Waples, 1985. Geochemistry in petroleum exploration, International Human Resources Development Corporation, Boston, 1-232.

[36] D.W.Waples, T.Machihara, 1991. Biomarkers for geologist-A Practical guide to the application of steranes and triterpanes in petroleum geology, American Association of Petroleum Geologists Methods in Exploration, No 9, The American Association of Petroleum Geologist, 1-91.

[37] C.Xiangchun, T.G.Wang, L.Qiming, C.Bin T.Xiaowan, 2013. Geochemistry and possible 
origin of petroleum in Palaeozoic reservoirs from Halahatang depression, Journal of Asian Earth Sciences 74, Elsevier, p 129-141.

[38] S.Zhang, H.Huang, 2005. Geochemistry of Palaeozoic marine petroleum from the Tarim Basin, NW China: Part 1. Oil family classification, Journal Organic Geochemistry 36, Elsevier, p 1204-1214.

[39] J.E.Zumberge, 1984. Source rocks of the La Luna Formation (Upper Cretaceous) in the Middle
Magdalena Valley, Colombia, in J.G. Palacas, ed., Geochemistry and Source Rock Potential of Carbonate Rocks, American Association of Petroleum Geologists Studies in Geology \#18, Tulsa, 127-133.

[40] J.E.Zumberge, 1987. Terpenoid biomarker distributions in low maturity crude oils. Journal Organic Geochemistry 11, Elsevier, p 479-496. 